\title{
Managerial Ability and Extreme Investment Behavior
}

\author{
Hsin-yi (Shirley) Hsieh ${ }^{1} \&$ Xuerong (Sharon) Huang ${ }^{2}$ \\ ${ }^{1}$ Department of Accounting, College of Business, Tennessee State University, Nashville, TN 37203, U.S.A. \\ ${ }^{2}$ Paul W. Parkison Department of Accounting, Miller College of Business, Ball State University, Muncie, IN 47306, \\ U.S.A.
}

Correspondence: Shirley Hsieh, Department of Accounting, College of Business, Tennessee State University, 330

$10^{\text {th }}$ Ave N, Nashville, TN 37203, U.S.A. E-mail: hhsieh@tnstate.edu

Received: August 27, 2019

Accepted: September 13, 2019

Online Published: September 16, 2019

doi:10.5430/afr.v8n4p57

URL: https://doi.org/10.5430/afr.v8n4p57

\begin{abstract}
This paper examines whether, why, and how managerial ability is associated with firms' investment behavior. Specifically, we focus on the effect of managerial ability on extreme investment behavior. We define expansionary (contractionary) investments as investing significantly more (less) than what is expected based on the firm's sales growth and industry membership. The baseline results reveal that more able managers are less likely to make contractionary investments, while they are more likely to make expansionary investments. We further propose and test the strategic investment hypothesis, which predicts that more able managers time the product markets and invest aggressively to ensure firms' future competitiveness. The evidence is supportive of this hypothesis: More able managers are more (less) likely to make expansionary (contractionary) investments when the industry (1) becomes more competitive, and (2) is at the onset of R\&D growth. Moreover, expansionary investments by more able managers are indeed their strategic investments, which lead to superior future abnormal returns.
\end{abstract}

Keywords: managerial ability, contractionary investments, expansionary investments, strategic investments, product markets

Mr. Hock Tan, Broadcom's CEO and the chip industry's most visible deal maker, has been helping drive profit growth at Broadcom, piling up cash and paying out dividends at a prodigious pace... He said he believes he spends more than necessary to maintain leadership in his core "franchises." "Frankly, we overinvest to ensure we are way ahead of No. 2 or No. 3," he said. (Note 1)

\section{Introduction}

As suggested by Bertrand and Schoar (2003), managers play a critical role in making corporate decisions and have direct impact on corporate policies and performance. Furthermore, Chang, Dasgupta, and Hilary (2010) and Demerjian, Lev, and McVay (2012) show that managerial ability is positively related to firms' stock returns in various settings. Despite the importance of managers and managerial ability for a firm documented in these studies, it is far less clear on whether, how, and why managerial ability affects corporate investment behavior, which could be an important channel through which managers affect firms' performance and stock return. In this paper, we evaluate the role of managerial ability on corporate investment behavior. Our study first examines whether managerial ability is associated with extreme levels of investments. We then try to explore the rationale of management for making seemingly excessive investments by testing the strategic investment hypothesis. This paper aims to fill in this gap and shed some lights on understanding the role of managerial ability on corporate investment.

How does managerial ability affect firms' overall investments and furthermore their strategic investments? As Demerjian et al. (2012) point out, “...We expect more able managers to better understand technology and industry trends, reliably predict product demand, invest in higher value projects, and manage their employees more efficiently than less able managers..." Following this definition, more able managers are better at identifying and investing in value enhancing projects. In our paper, we use the term "expansionary (contractionary) (Note 2) investments" to describe the situation wherein investments significantly exceed (fall below) what is expected based on the recent growth in the company's sales in the industry where the company operates. (Note 3) Therefore, ceteris 
paribus, more able managers are less likely to make contractionary investments as they are better at identifying higher value projects. However, whether more able managers would invest so much to a level significantly above what is normally expected (i.e. expansionary investments) remains ambiguous. On one hand, more able managers could be better at cost and budget management, thereby investing at just the right level that is necessary to sustain the growth of the company. On the other hand, existing studies show that strategic (over)investments may deter rivals from entry or expansion (Spence 1977, 1979; Dixit 1979; Fudenberg \& Tirole, 1983). More able managers may be "visionaries" and strategically invest more than current needs to ensure the firm's competitive advantages in the long run. Indeed, what seems to be excessive investment today, such as spending intensively on R\&Ds or overpaying to acquire a target that provides key technology or access to a new market, may enhance a firm's future competitiveness and performance. The earlier quote by Broadcom's CEO, Mr. Hock Tan, exemplifies this strategic investment view.

To empirically test the above conjectures, we adopt a recently developed managerial ability measure by Demerjian et al. (2012). The intuition behind this measure is how efficiently managers convert firms' resources to sales revenues relative to their industry peers in a given firm-year. Furthermore, we follow prior literature (e.g. Biddle, Hilary, \& Verdi 2009; Chen, Hope, Li, \& Wang 2011) to identify the cases of expansionary and contractionary investments based on the deviation of a firm's actual investment from its expected level of investment. Following Biddle et al. (2009) and Chen et al. (2011), the expected level of investment is estimated as a function of sales growth and varies across industries. In other words, we follow these studies and identify firm-years in which investments deviate notably from the expected level. Specifically, we form indicator variables equal to one if the level of the unexpected investments within a firm-year is in the top quartile (i.e., an indicator for expansionary investments) and the bottom quartile (i.e., an indicator for contractionary investments) of the residuals from the investment model, respectively, and zero otherwise.

Using a sample of 106,193 firm-year observations between 1989 and 2017, we find that more able managers are less likely to make contractionary investments. Moreover, more able managers are more likely to make expansionary investments. We conduct two additional analyses to mitigate potential endogeneity concerns. First, we implement an instrumental variable regression approach using the five-year lagged managerial ability measure as the instrument. Furthermore, we control for two measures of managerial overconfidence in the regressions to address the concern that the above findings on managerial ability are confounded by managerial overconfidence. In both analyses, we continue to find the same pattern: More able managers are less prone to engage in contractionary investments while more prone to make expansionary investments. (Note 4)

We then explore why more able managers are more likely to make expansionary investments while they are less prone to make contractionary investments. We find that more able managers are more (less) likely to make expansionary (contractionary) investments when the industry (1) becomes more competitive (measured by a decreasing Herfindahl Index of industry concentration), and (2) subsequently experiences higher future industry research and development (R\&D) growth. These results are consistent with the aforementioned "strategic investment" hypothesis: More able managers time the product markets and make seemingly excessive investments to ensure the firm's competitive advantage when the product markets show signs of increasing competition.

An alternative explanation for the above findings is that more able managers may time the product markets and make expansionary investments for self-serving motives, e.g., building their own empires instead of promoting the firm's future growth and competitiveness. To distinguish the strategic investment hypothesis from this self-serving motive, we examine firms' future stock returns, defined as the (time-series) mean of the abnormal stock returns three to five years from the observation year in question. We find that expansionary investments by more able managers lead to higher future abnormal stock returns. This finding lends further support to the strategic investment hypothesis. (Note 5)

This paper contributes to several lines of literature. First, this paper extends the literature on the effects of managerial ability. The existing literature shows that more able managers are associated with better performance (Chang et al., 2010; Demerjian et al., 2012), better earnings quality (Demerjian, Lev, Lewis \& McVay, 2013), more tax avoidance (Koester, Shevlin, \& Wangerin, 2016), lower credit risks (Cornaggia, Krishnan, \& Wang, 2017; Bonsall, Holzman, \& Miller, 2016), more intentional earnings smoothing (Demerjian, Lewis-Western, \& McVay, 2017), and more accurate management earnings forecast (Baik, Farber, \& Lee, 2011). Our study extends this line of research on the influence of managerial ability. Our study has implication to the practitioners by showing that corporate investment behaviors differs across different levels of managerial ability.

Second, this paper reconciles the mixed findings on the relation between managerial ability and corporate investment behavior. For example, Yung and Chen (2017) show that more able managers invest more than less able managers. 
Habib and Hasan (2017) report that more able managers are more likely to overinvest. However, Chen, Lai, Liu, and McVay (2014) find that more able managers reduce investment inefficiency. Most recently, Gan (2018) shows that more able managers reduce over- or under-investment for firms with certain characteristics that may make them more susceptible to over- or under-investment. Our study shows that more able managers are less likely to make contractionary investments; when they make expansionary investments, such investments seem to improve the firm's long-term performance. In addition to reconcile the baseline association between managerial ability and firms' investment behavior, we further examine the underlying reasons for this association. Overall, our study leads to a more comprehensive understanding of the relation between managerial ability and firms' investment behavior.

Third, our study further sheds light on whether and how managerial ability interacts with product markets, a question that remains largely unanswered in the literature. In particular, we present evidence that more able managers predict developments in product markets and make investments accordingly, thereby providing a possible explanation to the question why more able managers invest so much. This finding further supports more able managers as "visionaries" by Demerjian et al. (2012) and the conventional perception.

Finally, this paper contributes to the literature that examines the determinants of corporate investment behavior. Prior literature shows that information asymmetry, agency problem, and external financing affect investment behavior. Recent studies show that investment behavior is related to financial reporting quality (Biddle et al., 2009; Chen et al., 2011), product market concentration (Stoughton, Wong, \& Yi, 2017), business strategy (Navissi, Sridharan, Khedmati, Lim, \& Evdokimov, 2017), and stakeholders such as labor unions (Cho, Lee, Lee, \& Song, 2017). This paper sheds light on the debate of whether investors should bet on the jockey (managers) or the horse (the firm) (Kaplan, Sensoy, \& Stromberg, 2009) in the aspect of firms' investment behavior. Our study takes a further step and shows that the unexpected surge in investments might not be worrisome for a firm - in the presence of more able managers, expansionary investments could lead to superior future performance. This finding helps practitioners understand the possible positive effect of the expansionary investment made by more able managers.

The remainder of this paper proceeds as follows. In section 2, we develop the hypotheses to be tested in this paper. We then describe the research design and sample in section 3, followed by the discussion of results of the main empirical analysis in section 4 . Section 5 concludes our paper.

\section{Literature Review and Hypothesis Development}

One of the main takeaways from Modigliani and Miller (1958) is that a major source of a firm's value creation comes from value enhancing investments. Since Modigliani and Miller (1958), a large stream of literature has examined factors contributing to a firm's investment. (Note 6)These factors include information asymmetry between corporate insiders and the capital markets, agency problems, and the extent of external financing, among others. More recently, a growing literature investigates how managerial characteristics affect corporate investment behavior. For example, Bertrand and Schoar (2003) show that manager fixed effects matter for a variety of corporate policies and outcomes, while Malmendier and Tate (2005) suggest that managerial overconfidence can lead to investment distortions.

Understanding what makes an able manager is important for examining the relation between managerial ability and managers' investment behavior. General perceptions of managerial ability point to: 1) how managers evaluate their firms' relative position, including strength and weakness in their industry; 2) how efficiently managers allocate existing resources to maximize firm values; and 3) how managers envision industrial trend, technical opportunity and threats, and maintain/gain competitive advantage (Porter 1981). The quote from Demerjian et al. (2012) in the introduction is consistent with this view. An able manager is good at allocating existing resources to maximize firm values, knows how to make value enhancing projects, and can predict and react to future trends. When able managers see the opportunity and need to invest, they will pick up the projects to maintain or gain competitive advantage over their competitors. Therefore, more able managers are less likely to invest below the level necessary to sustain the growth of the company (i.e. contractionary investments). This leads to our first hypothesis, given in the alternative form as follows:

\section{H1: More able managers are less likely to make contractionary investments.}

However, whether more able managers would invest to an abnormally high level (i.e. expansionary investments) remains ambiguous. On one hand, more able managers may be better at controlling costs and budgets, so they are less likely to invest more than the amount necessary to sustain the growth. On the other hand, more able managers may expand the company due to self-serving or agency motives (e.g., Jensen \& Meckling, 1976). For example, more able managers may engage in expansionary investments to build their own empires to bolster their influences and 
increase their own pay. Alternatively, more able managers may strategically make expansionary investments for the firm's long-term benefits, to be detailed later. The ambiguity of the relation between managerial ability and expansionary investment leads to the following null hypothesis:

\section{H2: More able managers do not make expansionary investments.}

As described above, if more able managers are concerned about the firm's future growth and performance, they may strategically make expansionary investments. Indeed, the existing literature shows that firms which enter the product markets early can make preemptive investments to deter entry of potential competitors or investments by existing competitors (Spence 1977, 1979; Dixit 1979; Fudenberg \& Tirole, 1983). These "preemptive" investments, which seem excessive at the time and may even reduce short-term profits, might turn out to be valuable in the long run. In some cases, more able managers can make strategic expansionary investments to not only deter entry by potential competitors but also better compete against existing industry rivals. One such example is the Google-Motorola merger conducted in 2011. Google bought Motorola for 12.5 billion dollars, but later sold it to Lenovo for 2.9 billion dollars. (Note 7) On the surface, this seems to be a value destroying investment for Google; however, as Google's CEO Larry Page pointed out, "Motorola's patents have helped create a level playing field, which is good news for all Android's users and partners ... Google will retain the vast majority of Motorola's patents, which we will continue to use to defend the entire Android ecosystem." (Note 8) In other words, the merger provided Google with valuable patent portfolios to better compete in the smart phone markets and avoid intensive patent lawsuits. Other commentaries support this view. (Note 9)

If more able managers strategically make expansionary investments to ensure a firm's future competitiveness in the product markets, we should observe that these investments are made in a non-random fashion and coincide with product market changes. As more able managers are better at predicting industry trends, a reasonable conjecture is that they time investments when the product markets show signs of increasing competition.

Finally, if more able managers indeed strategically make expansionary investments for a firm's future (or long-term) benefits, we should expect that expansionary investments by more able managers lead to better future firm performance. This conjecture also helps distinguish the strategic investment motive from the self-serving or agency motive. Therefore,

H3 (Strategic Investment Hypothesis): More able managers make expansionary investments when product market competition intensifies; furthermore, expansionary investments by more able managers lead to better future firm performance.

\section{Research Design and Sample}

\subsection{Research Design}

We estimate the following model to test $\mathrm{H} 1$ and $\mathrm{H} 2$ :

$$
f(D V)_{i, t}=a_{0}+a_{1} \text { MANAGER_ABILITY } Y_{i, t-1}+\sum a_{j} \text { Controlsi }_{, t-1}+\varepsilon_{i, t}
$$

$D V$ represents the two dependent variables that proxy for extreme investment behavior: EXPAN and CONTRAC. We follow Biddle et al. (2009) and Chen et al. (2011) to measure unexpected investments as the residuals from the following investment model:

$$
\text { Invest }_{i, t}=b_{0}+b_{1} N E G_{i, t-1}+b_{2} \% \text { RevGrowth }_{i, t-1}+b_{3} N E G^{*} \% \text { RevGrowth }_{i, t-1}+\varepsilon_{i, t}
$$

Invest (the subscripts are omitted hereafter) is the sum of capital expenditure, $R \& D$ expense, and acquisitions less the proceeds from sale of property, plant, and equipment, scaled by lagged total assets. RevGrowth is the lagged sales growth rate. $N E G$ is an indicator variable coded as one if RevGrowth is negative and zero otherwise. We estimate the model by each industry-year with 10 or more observations. EXPAN and CONTRAC are indicator variables equal to one if the levels of unexpected investment during a firm-year are in the top and bottom quartiles of the residuals obtained from equation (2), respectively, and zero otherwise.

We use the managerial ability scores devised by Demerjian et al. (2012) as our main measure of managerial ability, MANAGER-ABILITY. Using a data envelope analysis, Demerjian et al. (2012) first construct an efficiency frontier based on how efficiently firms turn inputs into sales (Note 10). They then isolate the management effects by regressing firm deviations from the frontier on a variety of firm characteristics and use the residuals as the measure of managerial ability.

We estimate a Probit regression model in which the dependent variable is either EXPAN or CONTRAC to investigate if the coefficient on MANAGER_ABILITY is significantly different from zero. $\mathrm{H} 1$ (H2) predicts a negative (positive or 
negative) coefficient on MANAGER_ABILITY when the dependent variable is defined as CONTRAC (EXPAN). All the control variables for the effects of certain firm characteristics on investment levels, as well as their definitions, are reported in the Appendix. Finally, in all of the regressions, we control for industry and year fixed effects with standard errors clustered by firms. Industries are defined based on the Fama-French (1992) 48-industry classification.

To test the strategic investment hypothesis $(\mathrm{H} 3)$, we introduce the proxies for product market conditions and the following model:

$$
\begin{aligned}
& f(D V)_{i, t}=c_{0}+c_{1} \text { MANAGER_ABILITY }{ }_{i, t-1}+c_{2} \text { PRODUCT MARKET } T_{i, t} \\
& \quad+c_{3} \text { MANAGER_ABILITY } \\
& \text { M }
\end{aligned}
$$

The dependent variables are EXPAN and CONTRAC, as previously defined. PRODUCT MARKET represents the proxy for product market conditions.

We use two measures for PRODUCT MARKET: FUTURE CHANGE IN HHI is the time-series mean of the annual percentage change in the Herfindahl Index of industry concentration over the next three years; FUTURE IND. R\&D GROWTH is the time-series mean of the annual percentage change in industry research and development (R\&D) expenditures over the next three years. (Note 11) All the control variables are the same as those reported in equation (1).

To further examine whether expansionary investments by more able managers lead to superior future stock returns, we estimate the following model:

$$
\begin{aligned}
& f(D V)_{i, t}=d_{0}+d_{1} \text { MANAGER_ABILITY }{ }_{i, t-1}+d_{2} \text { EXPAN }_{i, t-1} \\
& \quad+d_{3} \text { MANAGER_ABILITY }{ }_{i, t-1} * E_{\text {EXPAN }}+\sum d_{j, t-1} \text { Controlsi }_{t,-1}+\varepsilon_{i, t}
\end{aligned}
$$

The dependent variables here are FUTURE RETURNS - the time-series mean of annual abnormal return three to five years following the observation year. Annual abnormal returns are the monthly abnormal returns (raw returns minus benchmark returns) compounding to the annual level. We use the following three benchmark returns: returns from the CRSP value-weighted index, returns from the CRSP equally-weighted index, and returns from the S\&P500 Index. Therefore, the three proxies for the dependent variables are FUTURE RETURNS(VW), FUTURE RETURNS(EW), and FUTURE RETURNS(SP).

\subsection{Sample Selection}

Our full sample used for testing H1, H2, and H3 contains 106,193 firm-year observations of non-financial companies for fiscal years 1989 - 2017. Our sample period begins from 1989 due to the availability of information of cash flows from operations. (Note 12) We obtained financial information required for measuring investment levels, stock returns, and other control variables from Compustat and CRSP. Data on the option-based managerial overconfidence measure come from Execucomp, and data on the media-based managerial overconfidence measure come from hand-collected information from news archives. (Note 13) All continuous variables in the samples are winsorized at 1 and 99 percent by fiscal year.

\subsection{Descriptive Statistics}

We report the descriptive statistics for the full sample in Panel A of Table 1. The mean value of MANAGER_ABILITY is 0.005 . We also report the residuals of unexpected investment (on which our main dependent variables EXPAN and CONTRAC are based) obtained from equation (2). The negative mean value of signed residuals is -.029 , indicating that the sample firms underinvest on average. As previously mentioned, EXPAN and CONTRAC are indicator variables equal to one if the levels of unexpected investment during a firm-year are in the top and bottom quartiles of the residuals obtained from equation (2), respectively. Panels B and C of Table 1 contrast the descriptive statistics for subsamples of expansionary and contractionary investments, respectively. The firms in the expansionary investment subsample appear to have more efficient management, as the mean (median) of MANAGER_ABILITY of sample firms in the expansionary investment subsample, 0.017 (-0.003), is higher than the mean (median), 0.003 $(-0.016)$, of those in the contractionary investment subsample. Firms engaging in expansionary investments also appear to have relatively more tangible assets in their asset mix, to have more cash at hand, and to pay more dividends. On the other hand, they also appear to be less levered, have fewer incidents of losses, and have less financial slack than those in the underinvestment subsample. These differences seem sensible given their different investment behaviors. Finally, we present the coefficients of correlation among all the variables used in this paper in Table 2. 
Table 1. Descriptive statistics Panel A. Full sample

\begin{tabular}{|c|c|c|c|c|c|c|c|c|}
\hline & $\underline{\mathrm{N}}$ & $\underline{\text { Mean }}$ & Std. Dev. & $\underline{10 \% \text { tile }}$ & $25 \%$ tile & $\underline{\text { Median }}$ & 75\% tile & $90 \%$ tile \\
\hline Residual (signed) & 106,193 & -0.029 & 0.435 & -0.199 & -0.112 & -0.043 & 0.029 & 0.161 \\
\hline MANAGER_ABILITY & 106,193 & 0.005 & 0.121 & -0.116 & -0.066 & -0.013 & 0.046 & 0.133 \\
\hline OVERCONFIDENCE - OPTION & 22,006 & 0.373 & 0.484 & 0.000 & 0.000 & 0.000 & 1.000 & 1.000 \\
\hline OVERCONFIDENCE - MEDIA & 11,868 & 4.358 & 1.177 & 2.833 & 3.664 & 4.419 & 5.069 & 5.811 \\
\hline FUTURE CHANGE IN HHI & 103,206 & 0.017 & 0.108 & -0.077 & -0.039 & 0.001 & 0.050 & 0.131 \\
\hline FUTURE IND. R\&D GROWTH & 102,930 & 0.021 & 0.422 & -0.125 & -0.014 & 0.056 & 0.115 & 0.208 \\
\hline FUTURE RETURNS (VW) & 67,153 & 0.041 & 0.384 & -0.351 & -0.167 & 0.000 & 0.177 & 0.445 \\
\hline FUTURE RETURNS (EW) & 67,153 & 0.013 & 0.354 & -0.354 & -0.180 & -0.021 & 0.147 & 0.387 \\
\hline FUTURE RETURNS (SP) & 67,153 & 0.061 & 0.394 & -0.343 & -0.155 & 0.018 & 0.203 & 0.477 \\
\hline SIZE & 106,193 & 5.031 & 2.410 & 1.976 & 3.326 & 4.919 & 6.633 & 8.285 \\
\hline MTB & 106,193 & 2.314 & 2.673 & 0.861 & 1.082 & 1.511 & 2.430 & 4.278 \\
\hline$A G E$ & 106,193 & 2.218 & 1.012 & 0.693 & 1.609 & 2.303 & 2.996 & 3.434 \\
\hline KSTRUCTURE & 106,193 & 0.169 & 0.217 & 0.000 & 0.000 & 0.076 & 0.265 & 0.505 \\
\hline TANG & 106,193 & 0.266 & 0.228 & 0.038 & 0.085 & 0.195 & 0.388 & 0.632 \\
\hline SLACK & 106,193 & 3.750 & 11.376 & 0.028 & 0.107 & 0.497 & 2.416 & 8.631 \\
\hline ZSCORE & 106,193 & 0.755 & 2.909 & -1.025 & 0.448 & 1.237 & 1.931 & 2.667 \\
\hline $\mathrm{CASH}$ & 106,193 & 0.193 & 0.215 & 0.009 & 0.031 & 0.107 & 0.283 & 0.532 \\
\hline DIVIDEND & 106,193 & 0.325 & 0.468 & 0.000 & 0.000 & 0.000 & 1.000 & 1.000 \\
\hline LOSS & 106,193 & 0.376 & 0.484 & 0.000 & 0.000 & 0.000 & 1.000 & 1.000 \\
\hline SIGMASALES & 106,193 & 0.313 & 0.323 & 0.059 & 0.110 & 0.211 & 0.395 & 0.679 \\
\hline SIGMACFO & 106,193 & 0.097 & 0.116 & 0.020 & 0.034 & 0.061 & 0.111 & 0.202 \\
\hline
\end{tabular}

Panel B. Expansionary investment sample

\begin{tabular}{|c|c|c|c|c|c|c|c|c|}
\hline & $\underline{\mathrm{N}}$ & Mean & Std. Dev. & $10 \%$ tile & $25 \%$ tile & $\underline{\text { Median }}$ & 75\% tile & $90 \%$ tile \\
\hline Residual (signed) & 26,543 & 0.247 & 0.434 & 0.041 & 0.064 & 0.122 & 0.261 & 0.562 \\
\hline MANAGER_ABILITY & 26,543 & 0.017 & 0.128 & -0.112 & -0.060 & -0.003 & 0.063 & 0.161 \\
\hline OVERCONFIDENCE - OPTION & 5,356 & 0.449 & 0.497 & 0.000 & 0.000 & 0.000 & 1.000 & 1.000 \\
\hline OVERCONFIDENCE - MEDIA & 3,118 & 4.169 & 1.208 & 2.565 & 3.466 & 4.277 & 4.927 & 5.624 \\
\hline FUTURE CHANGE IN HHI & 25,788 & 0.018 & 0.111 & -0.077 & -0.039 & 0.001 & 0.051 & 0.140 \\
\hline FUTURE IND. R\&D GROWTH & 25,681 & 0.023 & 0.417 & -0.118 & -0.010 & 0.056 & 0.115 & 0.202 \\
\hline FUTURE RETURNS (VW) & 17,355 & 0.039 & 0.410 & -0.378 & -0.186 & -0.005 & 0.184 & 0.459 \\
\hline FUTURE RETURNS (EW) & 17,355 & 0.011 & 0.379 & -0.384 & -0.198 & -0.026 & 0.152 & 0.413 \\
\hline FUTURE RETURNS (SP) & 17,355 & 0.058 & 0.420 & -0.371 & -0.176 & 0.012 & 0.209 & 0.490 \\
\hline SIZE & 26,543 & 4.755 & 2.327 & 1.729 & 3.160 & 4.711 & 6.315 & 7.808 \\
\hline MTB & 26,543 & 3.053 & 3.493 & 0.988 & 1.295 & 1.915 & 3.278 & 6.006 \\
\hline$A G E$ & 26,543 & 2.045 & 1.029 & 0.693 & 1.386 & 2.079 & 2.833 & 3.332 \\
\hline KSTRUCTURE & 26,543 & 0.119 & 0.175 & 0.000 & 0.000 & 0.033 & 0.176 & 0.366 \\
\hline TANG & 26,543 & 0.283 & 0.238 & 0.043 & 0.091 & 0.203 & 0.424 & 0.671 \\
\hline SLACK & 26,543 & 3.918 & 10.769 & 0.032 & 0.140 & 0.686 & 3.257 & 9.539 \\
\hline ZSCORE & 26,543 & 0.333 & 3.655 & -2.250 & 0.183 & 1.177 & 1.907 & 2.595 \\
\hline $\mathrm{CASH}$ & 26,543 & 0.238 & 0.233 & 0.013 & 0.046 & 0.157 & 0.370 & 0.609 \\
\hline DIVIDEND & 26,543 & 0.281 & 0.449 & 0.000 & 0.000 & 0.000 & 1.000 & 1.000 \\
\hline LOSS & 26,543 & 0.381 & 0.486 & 0.000 & 0.000 & 0.000 & 1.000 & 1.000 \\
\hline SIGMASALES & 26,543 & 0.326 & 0.316 & 0.064 & 0.120 & 0.230 & 0.419 & 0.697 \\
\hline SIGMACFO & 26,543 & 0.118 & 0.138 & 0.023 & 0.040 & 0.073 & 0.135 & 0.258 \\
\hline
\end{tabular}


Panel C. Contractionary investment sample

\begin{tabular}{|c|c|c|c|c|c|c|c|c|}
\hline & $\underline{\mathrm{N}}$ & Mean & Std. Dev. & $10 \%$ tile & $\underline{25 \% \text { tile }}$ & Median & 75\% tile & $90 \%$ tile \\
\hline Residual (signed) & 26,540 & -0.275 & 0.653 & -0.414 & -0.253 & -0.177 & -0.135 & -0.108 \\
\hline MANAGER_ABILITY & 26,540 & 0.003 & 0.129 & -0.122 & -0.069 & -0.016 & 0.041 & 0.129 \\
\hline OVERCONFIDENCE - OPTION & 4,275 & 0.363 & 0.481 & 0.000 & 0.000 & 0.000 & 1.000 & 1.000 \\
\hline OVERCONFIDENCE - MEDIA & 2,062 & 4.536 & 1.210 & 2.944 & 3.871 & 4.585 & 5.293 & 6.038 \\
\hline FUTURE CHANGE IN HHI & 25,991 & 0.005 & 0.100 & -0.096 & -0.047 & -0.005 & 0.029 & 0.117 \\
\hline FUTURE IND. R\&D GROWTH & 25,978 & 0.048 & 0.200 & -0.069 & 0.008 & 0.065 & 0.112 & 0.172 \\
\hline FUTURE RETURNS (VW) & 15,177 & 0.041 & 0.395 & -0.368 & -0.177 & -0.003 & 0.184 & 0.470 \\
\hline FUTURE RETURNS (EW) & 15,177 & 0.015 & 0.368 & -0.372 & -0.192 & -0.022 & 0.160 & 0.413 \\
\hline FUTURE RETURNS (SP) & 15,177 & 0.060 & 0.405 & -0.360 & -0.166 & 0.016 & 0.208 & 0.507 \\
\hline SIZE & 26,540 & 4.537 & 2.474 & 1.550 & 2.765 & 4.313 & 6.103 & 7.928 \\
\hline MTB & 26,540 & 2.344 & 2.838 & 0.828 & 1.049 & 1.482 & 2.435 & 4.425 \\
\hline$A G E$ & 26,540 & 2.188 & 0.979 & 0.693 & 1.609 & 2.303 & 2.944 & 3.367 \\
\hline KSTRUCTURE & 26,540 & 0.169 & 0.225 & 0.000 & 0.000 & 0.062 & 0.264 & 0.525 \\
\hline TANG & 26,540 & 0.228 & 0.226 & 0.025 & 0.059 & 0.145 & 0.323 & 0.604 \\
\hline$S L A C K$ & 26,540 & 5.490 & 15.492 & 0.033 & 0.143 & 0.715 & 3.377 & 13.174 \\
\hline ZSCORE & 26,540 & 0.353 & 3.330 & -1.685 & 0.050 & 0.967 & 1.706 & 2.473 \\
\hline $\mathrm{CASH}$ & 26,540 & 0.206 & 0.230 & 0.010 & 0.033 & 0.111 & 0.302 & 0.579 \\
\hline DIVIDEND & 26,540 & 0.256 & 0.437 & 0.000 & 0.000 & 0.000 & 1.000 & 1.000 \\
\hline LOSS & 26,540 & 0.466 & 0.499 & 0.000 & 0.000 & 0.000 & 1.000 & 1.000 \\
\hline SIGMASALES & 26,540 & 0.336 & 0.361 & 0.055 & 0.108 & 0.216 & 0.420 & 0.761 \\
\hline SIGMACFO & 26,540 & 0.110 & 0.131 & 0.021 & 0.038 & 0.069 & 0.128 & 0.235 \\
\hline
\end{tabular}

Description: Table 1 presents the descriptive statistics for the main variables used in our analyses. Panel A reports the descriptive statistics for the full sample. Panel B reports the descriptive statistics for the sample of firm-years that are characterized by expansionary investments. Panel $\mathrm{C}$ reports the descriptive statistics for the sample of firm-years that are characterized by contractionary investments. The construction of the variables is described in the Appendix.

Table 2. Correlation matrices

(1)EXPAN
(2)CONTRAC
(3)MANAGER_ABILITY
(4)OVERCONFIDENCE - OPTION
(5)OVERCONFIDENCE - MEDIA
(6)FUTURE CHANGE IN HHI
(7)FUTURE IND. R\&D GROWTH
(8)FUTURE RETURNS (VW)
(9)FUTURE RETURNS (EW)
(10)FUTURE RETURNS (SP)
(11)SIZE
(12)MTB
(13)AGE
(14)KSTRUCTURE
(15)TANG
(16)SLACK
(17)ZSCORE
(18)CASH
(19)DIVIDEND
(20)LOSS
(21)SIGMASALES
(22)SIGMACFO


Table 2. Correlation matrices (continued)

\begin{tabular}{|c|c|c|c|c|c|c|c|c|c|c|c|c|}
\hline & (11) & (12) & (13) & (14) & (15) & (16) & (17) & (18) & (19) & $(20)$ & $(21)$ & $(22)$ \\
\hline (1)EXPAN & -0.06 & 0.20 & -0.10 & -0.12 & 0.04 & 0.07 & -0.05 & 0.12 & -0.05 & 0.01 & 0.04 & 0.11 \\
\hline (2)CONTRAC & -0.13 & -0.02 & -0.02 & -0.02 & -0.13 & $\mathbf{0 . 0 8}$ & -0.12 & $\mathbf{0 . 0 2}$ & -0.08 & 0.11 & 0.02 & 0.07 \\
\hline (3)MANAGER_ABILITY & -0.10 & 0.22 & 0.01 & -0.25 & -0.27 & 0.24 & 0.27 & 0.16 & 0.00 & -0.18 & 0.23 & 0.15 \\
\hline (4)OVERCONFIDENCE - OPTION & -0.05 & 0.43 & -0.16 & -0.22 & -0.06 & 0.08 & 0.16 & $\mathbf{0 . 0 8}$ & -0.09 & -0.19 & 0.22 & 0.15 \\
\hline (5)OVERCONFIDENCE - MEDIA & 0.55 & -0.08 & 0.28 & 0.15 & 0.04 & -0.06 & -0.14 & -0.06 & 0.14 & $\mathbf{0 . 0 3}$ & -0.17 & -0.12 \\
\hline (6)FUTURE CHANGE IN HHI & 0.16 & -0.06 & $\mathbf{0 . 0 8}$ & $\mathbf{0 . 0 8}$ & 0.07 & -0.06 & -0.01 & -0.04 & 0.06 & 0.00 & -0.08 & -0.08 \\
\hline (7)FUTURE IND. R\&D GROWTH & -0.11 & 0.02 & -0.08 & -0.03 & -0.02 & $\mathbf{0 . 0 3}$ & 0.05 & $\mathbf{0 . 0 3}$ & -0.05 & 0.00 & 0.07 & 0.05 \\
\hline (8)FUTURE RETURNS (VW) & 0.07 & -0.01 & $\mathbf{0 . 0 3}$ & $\mathbf{0 . 0 3}$ & 0.02 & -0.02 & 0.04 & -0.02 & 0.02 & -0.06 & 0.00 & -0.04 \\
\hline (9)FUTURE RETURNS (EW) & 0.07 & -0.04 & 0.05 & 0.04 & 0.01 & -0.01 & 0.04 & -0.01 & 0.02 & -0.06 & -0.02 & -0.05 \\
\hline (10)FUTURE RETURNS (SP) & 0.07 & -0.01 & $\mathbf{0 . 0 3}$ & $\mathbf{0 . 0 3}$ & $\mathbf{0 . 0 2}$ & -0.02 & 0.04 & -0.02 & $\mathbf{0 . 0 2}$ & -0.06 & 0.01 & -0.04 \\
\hline (11)SIZE & & -0.12 & 0.25 & 0.32 & 0.24 & -0.21 & 0.19 & -0.16 & 0.43 & -0.35 & -0.28 & -0.53 \\
\hline (12)MTB & -0.27 & & -0.17 & -0.42 & -0.21 & 0.32 & -0.08 & 0.32 & -0.07 & 0.00 & 0.16 & 0.27 \\
\hline (13)AGE & 0.26 & -0.16 & & 0.13 & 0.11 & -0.15 & 0.19 & -0.16 & 0.31 & -0.18 & -0.17 & -0.24 \\
\hline (14)KSTRUCTURE & 0.22 & -0.26 & 0.09 & & 0.41 & -0.56 & -0.02 & -0.53 & 0.15 & -0.02 & -0.14 & -0.33 \\
\hline (15)TANG & 0.21 & -0.15 & 0.07 & 0.33 & & -0.74 & 0.04 & -0.40 & 0.23 & -0.11 & -0.18 & -0.26 \\
\hline (16)SLACK & -0.14 & 0.15 & -0.10 & -0.19 & -0.31 & & -0.13 & 0.89 & -0.22 & 0.12 & 0.07 & 0.30 \\
\hline (17)ZSCORE & 0.33 & -0.52 & 0.11 & $\mathbf{0 . 0 3}$ & $\mathbf{0 . 0 3}$ & -0.12 & & -0.16 & 0.24 & -0.62 & 0.30 & -0.17 \\
\hline (18) $\mathrm{CASH}$ & -0.20 & 0.26 & -0.22 & -0.40 & -0.40 & 0.54 & -0.14 & & -0.18 & 0.11 & -0.01 & 0.28 \\
\hline (19)DIVIDEND & 0.45 & -0.12 & 0.30 & 0.06 & 0.19 & -0.13 & 0.19 & -0.21 & & -0.31 & -0.19 & -0.35 \\
\hline (20)LOSS & -0.35 & 0.15 & -0.17 & 0.08 & -0.07 & 0.12 & -0.44 & 0.17 & -0.31 & & -0.01 & 0.28 \\
\hline (21)SIGMASALES & -0.26 & 0.17 & -0.15 & -0.10 & -0.18 & 0.01 & 0.04 & -0.04 & -0.16 & 0.01 & & 0.38 \\
\hline (22)SIGMACFO & -0.48 & 0.49 & -0.19 & -0.19 & -0.18 & 0.20 & -0.54 & 0.24 & -0.25 & 0.29 & 0.30 & \\
\hline
\end{tabular}

Description: Table 2 presents Pearson (lower left-hand side) and Spearman (upper right-hand side) correlation coefficient matrices for all firms in the sample. All variables are defined in the Appendix. Bold values indicate significance at the 0.10 level or stronger (based on two-tailed tests).

\section{Main Empirical Analysis}

\subsection{Managerial Ability and Investment Behavior: Baseline Results and Endogeneity Tests}

Table 3 reports the results of our tests of $\mathrm{H} 1$ and $\mathrm{H} 2$. We examine the effect of managerial ability on the likelihood of observing expansionary investments and contractionary investment separately. When examining the likelihood of contractionary investments, the significantly negative coefficient $(-0.622$, p-value < 0.0001$)$ on MANAGER_ABILITY shows that more able managers are less likely to make contractionary investments, consistent with the view that more able managers are better at identifying and investing in positive NPV projects. On the other hand, the positive coefficient $(0.558$, p-value < 0.0001$)$ on MANAGER_ABILITY indicates that more able managers are more prone to make expansionary investments, a finding consistent with both the self-serving motive and strategic investment hypothesis discussed in the section 2. We perform further tests (of H3) to distinguish between the two explanations in section 4.2 . 
Table 3. Managerial ability and investment behavior: Baseline results

\begin{tabular}{|c|c|c|c|}
\hline & \multirow[b]{2}{*}{$D V=$} & \multicolumn{2}{|c|}{ Binomial Probit Regression } \\
\hline & & $\underline{E X P A N}$ & CONTRAC \\
\hline \multirow[t]{2}{*}{ MANAGER_ABILITY } & & $0.558^{* * *}$ & $-0.622^{* * *}$ \\
\hline & & (10.09) & $(-8.98)$ \\
\hline \multirow[t]{2}{*}{ SIZE } & & 0.002 & $-0.062^{* * *}$ \\
\hline & & $(0.41)$ & $(-13.24)$ \\
\hline \multirow[t]{2}{*}{ MTB } & & $0.049^{* * *}$ & $-0.040^{* * *}$ \\
\hline & & $(17.14)$ & $(-11.69)$ \\
\hline \multirow[t]{2}{*}{$A G E$} & & $-0.087^{* * *}$ & $0.045^{* * *}$ \\
\hline & & $(-12.67)$ & $(5.77)$ \\
\hline \multirow[t]{2}{*}{ KSTRUCTURE } & & $-0.806^{* * *}$ & $0.522^{* * *}$ \\
\hline & & $(-22.93)$ & $(15.42)$ \\
\hline \multirow[t]{2}{*}{ TANG } & & $1.035^{* * *}$ & $-0.837^{* * *}$ \\
\hline & & $(24.32)$ & $(-18.67)$ \\
\hline \multirow[t]{2}{*}{ SLACK } & & $-0.008^{* * *}$ & $0.007^{* * *}$ \\
\hline & & $(-9.42)$ & $(10.48)$ \\
\hline \multirow[t]{2}{*}{ ZSCORE } & & $-0.007^{* *}$ & $-0.006^{*}$ \\
\hline & & $(-2.22)$ & $(-1.74)$ \\
\hline \multirow[t]{2}{*}{ CASH } & & $0.895^{* * *}$ & $-1.001^{* * *}$ \\
\hline & & $(21.12)$ & $(-20.61)$ \\
\hline \multirow[t]{2}{*}{ DIVIDEND } & & $-0.115^{* * *}$ & $0.093^{* * *}$ \\
\hline & & $(-6.93)$ & $(5.28)$ \\
\hline \multirow[t]{2}{*}{ LOSS } & & $-0.064^{* * *}$ & $0.043^{* * *}$ \\
\hline & & $(-4.77)$ & $(3.10)$ \\
\hline \multirow[t]{2}{*}{ SIGMASALES } & & -0.027 & $0.308^{* * *}$ \\
\hline & & $(-1.29)$ & $(14.84)$ \\
\hline \multirow[t]{2}{*}{ SIGMACFO } & & $0.330^{* * *}$ & $-0.155^{* *}$ \\
\hline & & $(4.95)$ & $(-2.16)$ \\
\hline Industry Fixed Effects & & Controlled & Controlled \\
\hline Year Fixed Effects & & Controlled & Controlled \\
\hline Intercept & & Included & Included \\
\hline $\mathrm{N}$ & & 106,193 & 106,193 \\
\hline $\mathrm{R}^{2} /$ Pseudo $\mathrm{R}^{2}$ & & 0.063 & 0.167 \\
\hline
\end{tabular}

Description: Table 3 reports estimates from the Probit regressions of EXPAN and CONTRAC on MANAGER_ABILITY and other control variables. $* * * / * * / *$ denotes significance at $1 \%, 5 \%$ and $10 \%$. We report Z-statistics in parentheses based on robust standard errors clustered by firm. All variables are defined in the Appendix. 
The baseline results reported in Table 3 could be subject to potential endogeneity issues. For example, it is possible that an unobservable factor is affecting both managerial ability and investment behavior, rendering spurious relations.

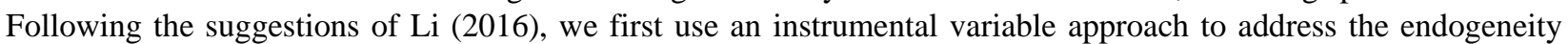
issue. Specifically, we use the five-year lagged managerial ability measure (LAGGED MANAGER_ABILITY (5 YEARS)) as the instrumental variable. The results are reported in Table 4.

In the first column of Table 4, we first report the estimates from the first stage (OLS) regressions. The coefficient on LAGGED MANAGER_ABILITY (5 YEARS) is positive and significant (0.444, p-value < 0.0001), suggesting that the instrumental variable meets the relevance criteria, i.e., the instrumental variable is correlated with our main variable of interest, MANAGER_ABILITY.

In the second and third column of Table 4, we then report estimates from the second stage (instrumental variable Probit) regressions of EXPAN and CONTRAC on MANAGER_ABILITY. The results reveal the same pattern as the baseline results: More able managers are less likely to make contractionary investments, while they are more likely to make expansionary investments. In the bottom of second and third column (Table 4), we also report the test statistics for the Wald exogeneity test. The insignificant test statistics of 0.31 and 0.72 , respectively, suggest that we are unable to reject the null hypotheses that MANAGER_ABILITY is exogenous under this instrumental variable Probit regression, adding to the validity of the instrument. Overall, the instrumental variable approach reassures the findings from the baseline regressions reported in Table 3.

The findings that more able managers are more (less) likely to make expansionary (contractionary) investments raises an additional concern that managerial ability may be positively correlated with managerial overconfidence. Indeed, more able managers may well be overconfident managers who are documented to invest excessively (Malmendier \& Tate 2005). Therefore, the above findings could be driven by managerial overconfidence instead of managerial ability. 
Table 4. Managerial ability and investment behavior: Instrumental variable regressions

\begin{tabular}{|c|c|c|c|}
\hline & \multirow[t]{2}{*}{$\begin{array}{l}\text { First Stage } \\
\text { Regression } \\
\quad(\text { OLS) }\end{array}$} & \multicolumn{2}{|c|}{ Binomial IV Probit Regression } \\
\hline & & $D V=\underline{E X P A N}$ & CONTRAC \\
\hline \multirow[t]{2}{*}{ MANAGER_ABILITY } & & $0.553^{* * *}$ & $-0.681^{* * *}$ \\
\hline & & $(3.76)$ & $(-3.90)$ \\
\hline \multirow[t]{2}{*}{ LAGGED MANAGER_ABILITY (5 YEARS) } & $0.444^{* * *}$ & & \\
\hline & $(46.14)$ & & \\
\hline \multirow[t]{2}{*}{ SIZE } & $0.003^{* * *}$ & 0.003 & $-0.058^{* * * *}$ \\
\hline & $(7.58)$ & $(0.59)$ & $(-10.77)$ \\
\hline \multirow[t]{2}{*}{$M T B$} & $0.008^{* * *}$ & $0.081^{* * *}$ & $-0.067^{* * *}$ \\
\hline & $(19.32)$ & $(16.08)$ & $(-10.83)$ \\
\hline \multirow[t]{2}{*}{$A G E$} & $0.007^{* * *}$ & $-0.091^{* * *}$ & $0.084^{* * *}$ \\
\hline & $(7.69)$ & $(-7.83)$ & $(6.41)$ \\
\hline \multirow[t]{2}{*}{ KSTRUCTURE } & $-0.020^{* * *}$ & $-0.775^{* * *}$ & $0.568^{* * * *}$ \\
\hline & $(-7.52)$ & $(-19.05)$ & (14.07) \\
\hline \multirow[t]{2}{*}{$T A N G$} & $-0.018^{* * *}$ & $1.033^{* * *}$ & $-0.877^{* * *}$ \\
\hline & $(-4.44)$ & $(19.89)$ & $(-15.86)$ \\
\hline \multirow[t]{2}{*}{ SLACK } & $0.001^{* * * *}$ & $-0.007^{* * *}$ & $0.008^{* * *}$ \\
\hline & $(5.37)$ & $(-6.54)$ & $(7.16)$ \\
\hline \multirow[t]{2}{*}{ ZSCORE } & $0.006^{* * *}$ & $-0.021^{* * *}$ & 0.002 \\
\hline & $(15.29)$ & $(-4.33)$ & $(0.35)$ \\
\hline \multirow[t]{2}{*}{$\mathrm{CASH}$} & 0.003 & $0.772^{* * *}$ & $-0.811^{* * *}$ \\
\hline & $(0.65)$ & $(13.76)$ & $(-12.28)$ \\
\hline \multirow[t]{2}{*}{ DIVIDEND } & 0.002 & $-0.119^{* * *}$ & $0.085^{* * *}$ \\
\hline & $(1.62)$ & $(-6.08)$ & $(4.11)$ \\
\hline \multirow[t]{2}{*}{ LOSS } & $-0.021^{* * *}$ & $-0.081^{* * *}$ & $0.046^{* * * *}$ \\
\hline & $(-19.37)$ & $(-4.91)$ & $(2.77)$ \\
\hline \multirow[t]{2}{*}{ SIGMASALES } & $0.013^{* * *}$ & -0.026 & $0.350^{* * * *}$ \\
\hline & $(5.67)$ & $(-0.88)$ & $(12.32)$ \\
\hline \multirow[t]{2}{*}{ SIGMACFO } & $0.132^{* * *}$ & $0.678^{* * *}$ & $-0.346^{* * *}$ \\
\hline & $(14.03)$ & $(6.31)$ & $(-2.94)$ \\
\hline Wald Test of Exogeneity & & 0.31 & 0.72 \\
\hline Industry Fixed Effects & Controlled & Controlled & Controlled \\
\hline Year Fixed Effects & Controlled & Controlled & Controlled \\
\hline Intercept & Included & Included & Included \\
\hline $\mathrm{N}$ & 78,125 & 78,125 & 78,125 \\
\hline $\mathrm{R}^{2} /$ Pseudo $\mathrm{R}^{2}$ & 0.365 & - & - \\
\hline
\end{tabular}

Description: Table 4 reports estimates from the instrumental variable Probit (IV Probit) regressions of EXPAN and CONTRAC on MANAGER_ABILITY and other control variables. In the first column, we report estimates from the first-stage (OLS) regression of MANAGER_ABILITY on LAGGED MANAGER_ABILITY (5 YEARS) and other control variables. In the second (third) column, we report estimates from the IV Probit regressions of EXPAN $(C O N T R A C)$ on the fitted value of MANAGER_ABILITY and other control variables. ***/**/* denotes significance 
at $1 \%, 5 \%$ and $10 \%$. In column 1 , we report t-statistics in parentheses based on robust standard errors clustered by firm. In columns 2 and 3, we report Z-statistics in parentheses based on robust standard errors clustered by firm. All variables are defined in the Appendix.

Table 5. Managerial ability, overconfidence, and investment behavior

\begin{tabular}{|c|c|c|c|c|c|}
\hline \multirow{2}{*}{\multicolumn{2}{|c|}{$D V=$}} & \multicolumn{4}{|c|}{ Binomial Probit Regression } \\
\hline & & EXPAN & CONTRAC & EXPAN & CONTRAC \\
\hline \multirow[t]{2}{*}{ MANAGER_ABILITY } & & $0.427^{* * *}$ & $-0.900^{* * *}$ & $0.570^{* * *}$ & $-1.005^{* *}$ \\
\hline & & $(4.10)$ & $(-7.14)$ & $(3.73)$ & $(-5.56)$ \\
\hline \multirow[t]{2}{*}{$\begin{array}{l}\text { OVERCONFIDENCE } \\
\text { - OPTION }\end{array}$} & & $0.105^{* * *}$ & -0.036 & & \\
\hline & & $(4.18)$ & $(-1.21)$ & & \\
\hline \multirow{3}{*}{$\begin{array}{l}\text { OVERCONFIDENCE - } \\
\text { - MEDIA }\end{array}$} & & & & & \\
\hline & & & & 0.006 & -0.010 \\
\hline & & & & $(0.34)$ & $(-0.45)$ \\
\hline \multirow[t]{2}{*}{ SIZE } & & $-0.086^{* * *}$ & $0.050^{* * *}$ & $-0.098^{* * * *}$ & $0.086^{* *}$ \\
\hline & & $(-6.91)$ & $(3.87)$ & $(-5.53)$ & $(4.18)$ \\
\hline \multirow[t]{2}{*}{ MTB } & & $0.062^{* * *}$ & $-0.082^{* * * *}$ & $0.049^{* * *}$ & $-0.030^{* * *}$ \\
\hline & & $(6.08)$ & $(-5.77)$ & $(5.15)$ & $(-2.38)$ \\
\hline \multirow[t]{2}{*}{$A G E$} & & $-0.040^{* * *}$ & 0.033 & $-0.068^{* * * *}$ & $0.049^{*}$ \\
\hline & & $(-2.26)$ & $(1.63)$ & $(-3.01)$ & $(1.77)$ \\
\hline \multirow[t]{2}{*}{ KSTRUCTURE } & & $-1.064^{* * *}$ & $0.811^{* * *}$ & $-1.330^{* * *}$ & $0.935^{* *}$ \\
\hline & & $(-10.87)$ & (7.88) & $(-10.80)$ & $(7.01)$ \\
\hline \multirow[t]{2}{*}{ TANG } & & $1.154^{* * *}$ & $-1.437^{* * * *}$ & $1.251^{* * *}$ & $-1.491^{* *}$ \\
\hline & & $(11.22)$ & $(-13.28)$ & $(9.42)$ & $(-10.17)$ \\
\hline \multirow[t]{2}{*}{$S L A C K$} & & $-0.009^{* * *}$ & $0.009^{* *}$ & $-0.024^{* * *}$ & $0.037^{* *}$ \\
\hline & & $(-2.65)$ & $(2.40)$ & $(-3.38)$ & $(4.26)$ \\
\hline \multirow[t]{2}{*}{ ZSCORE } & & $-0.089^{* * *}$ & $0.080^{* * *}$ & $-0.087^{* * *}$ & $0.085^{* *}$ \\
\hline & & $(-4.40)$ & $(3.37)$ & $(-3.33)$ & $(2.53)$ \\
\hline \multirow[t]{2}{*}{$\mathrm{CASH}$} & & $0.623^{* * *}$ & $-0.758^{* * *}$ & $0.601^{* * *}$ & $-1.073^{* *}$ \\
\hline & & $(5.00)$ & $(-4.81)$ & $(3.49)$ & $(-4.82)$ \\
\hline \multirow[t]{2}{*}{ DIVIDEND } & & $-0.133^{* * *}$ & $0.143^{* * *}$ & $-0.129^{* * * *}$ & $0.120^{* *}$ \\
\hline & & $(-4.10)$ & $(3.64)$ & $(-3.06)$ & $(2.33)$ \\
\hline \multirow[t]{2}{*}{ LOSS } & & $-0.150^{* * *}$ & $0.074^{* *}$ & $-0.144^{* * *}$ & $0.143^{* *}$ \\
\hline & & $(-4.26)$ & (1.97) & $(-3.02)$ & $(2.62)$ \\
\hline \multirow[t]{2}{*}{ SIGMASALES } & & 0.020 & $0.519^{* * *}$ & 0.059 & $0.317^{* *}$ \\
\hline & & $(0.29)$ & $(6.78)$ & $(0.76)$ & $(3.42)$ \\
\hline \multirow[t]{2}{*}{ SIGMACFO } & & $1.447^{* * *}$ & -0.574 & $1.570^{* * *}$ & -0.481 \\
\hline & & (4.16) & $(-1.30)$ & $(3.81)$ & $(-0.92)$ \\
\hline \multicolumn{2}{|l|}{ Industry Fixed Effects } & Controlled & Controlled & Controlled & Controlled \\
\hline \multicolumn{2}{|l|}{ Year Fixed Effects } & Controlled & Controlled & Controlled & Controlled \\
\hline \multicolumn{2}{|l|}{ Intercept } & Included & Included & Included & Included \\
\hline \multicolumn{2}{|l|}{$\mathrm{N}$} & 22,006 & 21,831 & 11,868 & 11,766 \\
\hline \multicolumn{2}{|l|}{$\mathrm{R}^{2} /$ Pseudo $\mathrm{R}^{2}$} & 0.082 & 0.259 & 0.091 & 0.261 \\
\hline
\end{tabular}

Description: Table 5 reports estimates from the Probit regressions of EXPAN and CONTRAC on MANAGER_ABILITY, two measures of manager overconfidence (OVERCONFIDENCE - OPTION and 
OVERCONFIDENCE - MEDIA), and other control variables. ***/**/* denotes significance at $1 \%, 5 \%$ and $10 \%$. We report Z-statistics in parentheses based on robust standard errors clustered by firm. All variables are defined in the Appendix.

Although the instrumental variable approach reported in Table 4 should address this potential omitted variable issue, we perform further tests to ensure the robustness of our findings. In Table 5, we include two often-used measures of managerial overconfidence - an option-based overconfidence measure (OVERCONFIDENCE - OPTION) and a media-based overconfidence measure (OVERCONFIDENCE -- MEDIA) - in the baseline regressions. After including these two managerial overconfidence variables, MANAGER_ABILITY still has a positive (negative) and significant impact on EXPAN (CONTRAC). This result further confirms our baseline findings. Note that, due to data limitations, the number of observations drops significantly after the inclusion of the managerial overconfidence measures (from 106,193 to around 22,000 or even less). To avoid potential biases due to this much smaller sample, in what follows we only report regression results without the inclusion of the managerial overconfidence variables.

\subsection{Managerial Ability and Investment Behavior: Strategic Investment Hypothesis}

The previous subsection provides the baseline findings that more able managers are more (less) likely to make expansionary (contractionary) investments. In this section, we further test $\mathrm{H} 3$ - the strategic investment hypothesis, under which more able managers make expansionary investments when product market competition becomes fiercer. Table 6 reports the estimation results based on equation (3). Specifically, in columns 1 and 2, when the industry becomes more competitive within the next three years (measured by a decrease in the (time-series) mean percentage change in annual Herfindahl Index, FUTURE CHANGE IN HHI), more able managers are more (less) likely to make expansionary (contractionary) investments. This result suggests that more able managers time the product market (when it becomes more competitive) and make expansionary investments accordingly.

As reported in section 3.1, we use another variable indicating a more competitive future product market: the (time-series) mean of annual industry R\&D growth within the next three years (FUTURE IND. R\&D GROWTH). A higher industry $R \& D$ growth is indicative of potential race in $R \& D$ and technologies and thus signals intensifying competitions. In columns 3 to 4 (Table 6), we find that more able managers are more (less) likely to make expansionary (contractionary) investments with an increase in FUTURE IND. R\&D GROWTH. The results further confirm the previous finding.

However, the findings in Table 6 alone cannot rule out more able managers' self-serving motives: They are better at predicting industry trends and make expansionary investments not for the long-term benefits of the firm, but to build their own empires. To further distinguish between these two hypotheses, in Table 7 we report estimates from equation (4), with the dependent variables as FUTURE RETURNS, which are the (time-series) mean of a firm's abnormal stock returns three to five years following the observation year. As mentioned in section 3.1, we employ three measures of future returns to ensure robustness of the results across different benchmarks: FUTURE RETURNS(VW), FUTURE RETURNS(EW), and FUTURE RETURNS(SP). The main explanatory variable of interest is MANAGER_ABILITY*EXPAN, an interaction term of the managerial ability and the indicator for expansionary investments. 
Table 6. Managerial ability, product markets, and investment behavior

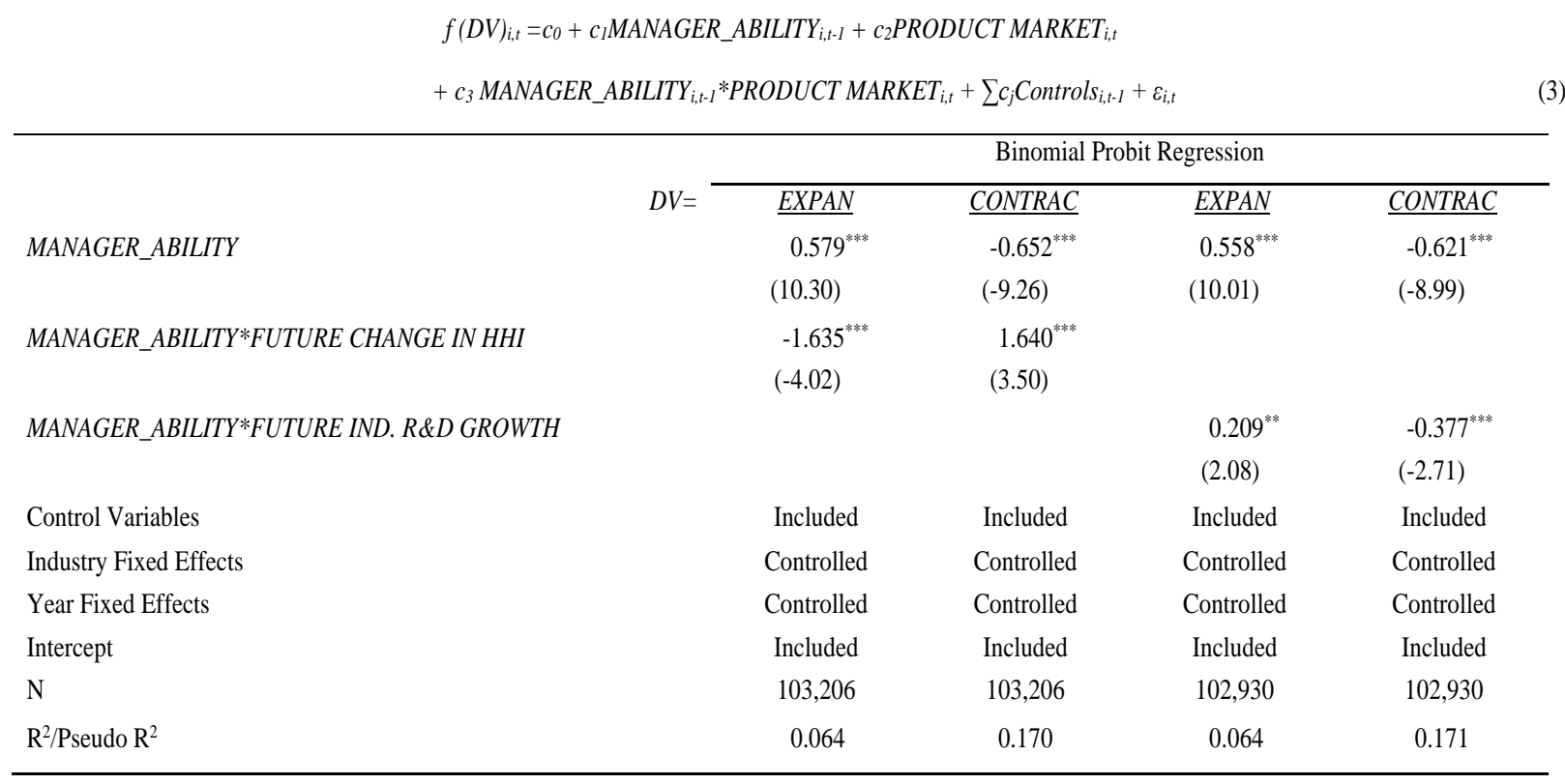

Description: Table 6 reports estimates from the Probit regressions of EXPAN and CONTRAC on MANAGER_ABILITY, the interaction term of MANAGER_ABILITY and PRODUCT MARKET, and other control variables. The two measures of PRODUCT MARKET are FUTURE CHANGE IN HHI and FUTURE IND. R\&D GROWTH. $* * * / * * / *$ denotes significance at $1 \%, 5 \%$ and $10 \%$. We report Z-statistics in parentheses based on robust standard errors clustered by firm. All variables are defined in the Appendix.

In columns 1 to 3 (Table 7), the positive and significant coefficients on the interaction term, MANAGER_ABILITY*EXPAN, suggest that expansionary investments by more able managers indeed lead to superior future stock returns. In columns 4 to 6 (Table 7), we turn our attention to examining how the interaction term MANAGER_ABILITY*CONTRAC would affect future returns. First of all, the coefficients on CONTRAC are negative and significant; furthermore, the coefficients on interaction term MANAGER_ABILITY*CONTRAC are insignificant. Taken together, these findings suggest that current contractionary investments lead to worse future stock returns regardless of the managerial ability. Overall, the results reported in Table 7 further supports the strategic investment hypothesis.

Finally, in unreported tables, we perform robustness tests by examining alternative dependent and independent variables. We perform all the empirical tests using investment measures derived from the investment model used by Biddle et al. (2009) and obtain similar results. We also replace the managerial ability measure by decile ranks as well as by alternative measures used in prior literature, such as CEO total compensation and company stock returns. The results using alternative measures of managerial ability do not materially change. 
Table 7. Managerial ability, investment behavior, and future returns

$f(D V)_{i, t}=d_{0}+d_{l}$ MANAGER_ABILITY $Y_{i, t-l}+d_{2} \operatorname{EXPAN}_{i, t-1}+d_{3}$ MANAGER_ABILITY $_{i, t-1} * \operatorname{EXPAN}_{i, t-1}+\sum d_{j}$ Controlsi $_{t,-l}+\varepsilon_{i, t}$

\begin{tabular}{|c|c|c|c|c|c|c|c|}
\hline & \multicolumn{7}{|c|}{ OLS Regression } \\
\hline & $D V=$ & $\underline{\underline{\text { RETURNS }(V W)}}$ & $\frac{\frac{F U T U R E}{R E T U R N S}}{\frac{(E W)}{(E)}}$ & $\underline{\underline{\text { FUTURE }}} \underline{\underline{T U R N S(S P)}}$ & $\begin{array}{l}\frac{\text { FUTURE }}{\text { RETURNS }} \\
\frac{(V W)}{}\end{array}$ & $\begin{array}{l}\frac{\text { FUTURE }}{\text { RETURNS }} \\
\frac{(E W)}{E}\end{array}$ & $\begin{array}{l}\frac{\text { FUTURE }}{\text { RETURNS }} \\
\frac{(S P)}{L}\end{array}$ \\
\hline \multirow[t]{2}{*}{ MANAGER_ABILITY } & & -0.015 & -0.004 & -0.018 & -0.001 & 0.008 & -0.003 \\
\hline & & $(-0.92)$ & $(-0.24)$ & $(-1.03)$ & $(-0.07)$ & $(0.47)$ & $(-0.16)$ \\
\hline \multirow[t]{2}{*}{ MANAGER_ABILITY*EXPAN } & & $0.061^{* * *}$ & $0.056^{*}$ & $0.062^{* *}$ & & & \\
\hline & & $(2.00)$ & $(1.95)$ & $(2.01)$ & & & \\
\hline \multirow[t]{2}{*}{ MANAGER_ABILITY*CONTRAC } & & & & & 0.005 & 0.007 & 0.005 \\
\hline & & & & & $(0.19)$ & $(0.28)$ & $(0.18)$ \\
\hline \multirow[t]{2}{*}{ EXPAN } & & 0.007 & 0.006 & 0.007 & & & \\
\hline & & $(1.63)$ & $(1.64)$ & $(1.57)$ & & & \\
\hline \multirow[t]{2}{*}{ CONTRAC } & & & & & $-0.019^{* * *}$ & $-0.019^{* * *}$ & $-0.019^{* * *}$ \\
\hline & & & & & $(-4.21)$ & $(-4.24)$ & $(-4.15)$ \\
\hline Control Variables & & Included & Included & Included & Included & Included & Included \\
\hline Industry Fixed Effects & & Controlled & Controlled & Controlled & Controlled & Controlled & Controlled \\
\hline Year Fixed Effects & & Controlled & Controlled & Controlled & Controlled & Controlled & Controlled \\
\hline Intercept & & Included & Included & Included & Included & Included & Included \\
\hline $\mathrm{N}$ & & 67,153 & 67,153 & 67,153 & 67,153 & 67,153 & 67,153 \\
\hline $\mathrm{R}^{2} /$ Pseudo $\mathrm{R}^{2}$ & & 0.068 & 0.012 & 0.081 & 0.067 & 0.012 & 0.080 \\
\hline
\end{tabular}

Description: Table 7 reports estimates from the OLS regressions of FUTURE RETURNS on MANAGER_ABILITY, the interaction term of MANAGER_ABILITY and EXPAN, and other control variables. The three measures of FUTURE RETURNS are FUTURE RETURNS(VW), FUTURE RETURNS(EW), and FUTURE RETURNS(SP). $* * * / * * / *$ denotes significance at $1 \%, 5 \%$ and $10 \%$. We report t-statistics in parentheses based on robust standard errors clustered by firm. All variables are defined in the Appendix.

\section{Conclusion}

In this paper, we examine whether, how and why managerial ability affects corporate investment behavior. The baseline results indicate that more able managers are more likely to make expansionary investments, while they are less likely to make contractionary investments. We then propose and test the strategic investment hypothesis, in which more able managers time product market conditions and expand investment accordingly to ensure the firm's future competitiveness. Consistent with this hypothesis, more able managers are more (less) likely to make expansionary (contractionary) investments when the product markets become more competitive and when the industry experiences higher future R\&D growth. Furthermore, expansionary investments by more able managers lead to superior future abnormal returns.

This paper makes several contributions to the existing literature. First, our paper extends the literature on the influence of managerial ability by examining the relation between managerial ability and managers' investment choices. Second, this paper helps reconcile the conflicting findings on the relation between managerial ability and corporate investment behavior in the prior literature. Our study attempts to provide a comprehensive understanding of the underlying scenario for the mixed findings. Third, our findings suggest the possible link between managerial ability and product markets. In particular, we find that more able managers make investments according to product market conditions. However, the role and the effects of more able managers in a firm's product markets are far from clear. More research is called for to further investigate these issues. Finally, our study contributes to the literature that examines the determinants of corporate investment behavior. Our results suggest that in addition to firm characteristics, manager characteristics also influence corporate investment behavior.

\section{Acknowledgements}

We thank Stephen Avila, Doug Ayres, Fadi Fawaz, Kris Kemper, Mark Myring, Erik Nesson, Tiffany Westfall, and all participants at the Miller College research colloquium at Ball State University for their valuable comments. We 
especially thank Scott Hsu for his input into earlier versions of this paper. All remaining errors are our own.

\section{References}

Baik, B., Farber, D. B. \& Lee, S. (2011). CEO ability and management earnings forecasts. Contemporary Accounting Research, 28(5), 1645-1668.https://doi.org/10.1111/j.1911-3846.2011.01091.x

Bertrand, M. \& Schoar, A. (2003). Managing with style: the effect of managers on firm policies. The Quarterly Journal of Economics, 118(4), 1169-1208.https://doi.org/10.1162/003355303322552775

Biddle, G. C., Hilary, G. \& Verdi, R. S. (2009). How does financial reporting quality relate to investment efficiency? Journal of Accounting and Economics, 48, 112-131.https://doi.org/10.1016/j.jacceco.2009.09.001

Bonsall, S. B., Holzman, E. R. \& Miller, B. P. (2016). Managerial ability and credit risk assessment. Management Science, 63(5), 1425-1449. https://doi.org/10.1287/mnsc.2015.2403

Chang, Y. Y., Dasgupta, S. \& Hilary, G. (2010). CEO ability, pay, and firm performance. Management Science, 56(10), 1633-1652. https://doi.org/10.1287/mnsc.1100.1205

Chen F., Hope, O.-K., Li, Q. \& Wang, X. (2011). Financial reporting quality and investment efficiency of private firms in emerging markets. The Accounting Review, 86(4), 1255-1288.https://doi.org/10.2308/accr-10040

Chen, S.-S., Lai, S. M., Liu, C. L. \& McVay, S. E. (2014). Overconfident managers and internal controls. Working Paper. Retrieved from https://papers.ssrn.com/abstract=2510137.https://doi.org/10.2139/ssrn.2510137

Cho, H, Lee, B. B., Lee, W.-J. \& Sohn, B. C. (2017). Do labor unions always lead to underinvestment? Journal of Management Accounting Research, 29(1), 45-66. https://doi.org/10.2308/jmar-51534

Cole, J. F. \& Li, Z. F. (2018). Managerial attributes, incentives, and performance. Working Paper. Retrieved from https://papers.ssrn.com/sol3/papers.cfm?abstract_id=1680484.

Cole, J. F. \& Li, Z. F. (2019). An empirical assessment of empirical corporate finance. Working Paper. Retrieved from https://papers.ssrn.com/sol3/papers.cfm?abstract_id=1787143.

Cornaggia, K. J., Krishnan, G. V. \& Wang, C. (2017). Managerial ability and credit ratings. Contemporary Accounting Research, 34(4), 2094-2122. https://doi.org/10.1111/1911-3846.12334

Demerjian, P., Lev, B. \& McVay, S. (2012). Quantifying managerial ability: A new measure and validity tests. Management Science, 58(7), 1229-1248.https://doi.org/10.1287/mnsc.1110.1487

Demerjian, P. R., Lev, B., Lewis, M. F. \& McVay, S. E. (2013). Managerial ability and earnings quality. The Accounting Review, 88(2), 463-498.https://doi.org/10.2308/accr-50318

Demerjian, P., B. Lev, Lewis-Western, M. \& McVay, S. (2017). How does intentional earnings smoothing vary with managerial ability? Journal of Accounting, Auditing, and Finance, December 27, 2017. https://doi.org/10.1177/0148558X17748405

Dixit, A. (1979). A model of duopoly suggesting a theory of entry barriers. The Bell Journal of Economics, 10(1), 20-32.https://doi.org/10.2307/3003317

Fama, E. F. \& French, K. R. (1992). The cross-section of expected stock returns. The Journal of Finance, 47(2), 427-465.https://doi.org/10.1111/j.1540-6261.1992.tb04398.x

Fudenberg, D. \& Tirole, J. (1983). Capital as a commitment: Strategic investment to deter mobility. Journal of Economic Theory, 31(2), 227-250.https://doi.org/10.1016/0022-0531(83)90075-3

Gan, H. (2018). Does CEO managerial ability matter? Evidence from corporate investment efficiency. Review of Quantitative Finance and Accounting, May 23, 2018. https://doi.org/10.1007/s11156-018-0737-2

Habib, A. \& Hasan, M. M. (2017). Managerial ability, investment efficiency and stock price crash risk. Research in International Business and Finance, 42, 262-274.https://doi.org/10.1016/j.ribaf.2017.07.048

Jensen, M. C. \& Meckling, W. H. (1976). Theory of the firm: Managerial behavior, agency costs and ownership structure. Journal of Financial Economics, 3(4), 305-360.https://doi.org/10.1016/0304-405X(76)90026-X

Kaplan, S. N., Sensoy, B. A. \& Strömberg, P. (2009). Should investors bet on the jockey or the horse? Evidence from the evolution of firms from early business plans to public companies. The Journal of Finance, 64(1), 75-115https://doi.org/10.1111/j.1540-6261.2008.01429.x. 
Koester, A., Shevlin, T. \& Wangerin, D. (2016). The role of managerial ability in corporate tax avoidance. Management Science, 63(10), 3285-3310.https://doi.org/10.1287/mnsc.2016.2510

Li, F. (2016). Endogeneity in CEO power: A survey and experiment. Investment Analysts Journal, 45(3), 149-162.https://doi.org/10.1080/10293523.2016.1151985

Malmendier, U. \& Tate, G. (2005). CEO overconfidence and corporate investment. The Journal of Finance, 60(6), 2661-2700.https://doi.org/10.1111/j.1540-6261.2005.00813.x

Modigliani, F. \& Miller, M. H. (1958). The cost of capital, corporation finance and the theory of investment. The American Economic Review, 48(3), 261-297.

Navissi, F., Sridharan, V. G., Khedmati, M., Lim, E. K. \& Evdokimov, E. (2017). Business strategy, over- (under-) investment, and managerial compensation. Journal of Management Accounting Research, 29(2), 63-86.https://doi.org/10.2308/jmar-51537

Porter, M. F. (1981). The contributions of industrial organization to strategic management. Academy of Management Review, 6(4), 609-620.https://doi.org/10.5465/amr.1981.4285706

Spence, A. M. (1977). Entry, capacity, investment, and oligopolistic pricing. The Bell Journal of Economics, 8(2), 534-544.https://doi.org/10.2307/3003302

Spence, A. M. (1979). Investment strategy and growth in a new market. The Bell Journal of Economics, 10(1), 1-19. https://doi.org/10.2307/3003316

Stein, J. C. (2003). Agency, information and corporate investment. Handbook of the Economics of Finance, 1, 111-165.https://doi.org/10.1016/S1574-0102(03)01006-9

Stoughton, N. M., Wong, K. P. \& Yi, L. (2017). Investment efficiency and product market competition. Journal of Financial and Quantitative Analysis, 52(6), 2611-2642. https://doi.org/10.1017/S0022109017000746

Yung, K. \& Chen, C. (2017). Managerial ability and firm risk-taking behavior. Review of Quantitative Finance and Accounting, December 22, 2017. https://doi.org/10.1007/s11156-017-0695-0

\section{Appendix: Variable Definitions}

Main Dependent and Independent Variables

EXPAN

CONTRAC

MANAGER_ABILITY

OVERCONFIDENCE-OPTION
An indicator variable equals 1 for the top quartile of the rank of the residuals from the investment model, and 0 otherwise.

An indicator variable equals 1 for the bottom quartile of the rank of the residuals from the investment model, and 0 otherwise.

Managerial ability score from Demerjian et al. (2012), calculated using data envelopment analysis (DEA) where total sales is optimized using the vector of inputs including net PP\&E, operating leases, $R \& D$, purchased goodwill and intangibles, cost of goods sold, and SG\&A. The DEA is optimized at the industry and year levels, and a firm efficiency score is calculated. The firm efficiency score is then regressed on firm characteristics (size, market share, positive free cash flow, age, business segment concentration, a foreign currency indicator, and year indicators), and the residual from this regression is the managerial ability score.

An indicator variable equals 1 for if the ratio of realizable value of unexercised, exercisable stock options of the CEO to the strike prices of the options is greater than 0.67 in the previous year, and 0 otherwise. We follow the procedures described by Chen, Lai, Liu, and McVay (2014) to estimate the ratio. 
OVERCONFIDENCE - MEDIA

FUTURE CHANGE IN HHI

FUTURE IND. R\&D GROWTH

FUTURE RETURNS (VW)

FUTURE RETURNS (EW)

FUTURE RETURNS (SP)

Control Variables

SIZE

$M T B$

AGE

KSTRUCTURE

TANG

SLACK

ZSCORE

CASH

DIVIDEND

LOSS

SIGMASALE

SIGMACFO
The natural logarithm of one plus the number of news articles citing the names of the CEO and the company in the 5 years preceding current fiscal year.

Time-series mean of the annual percentage change in the Herfindahl Index of industry concentration over the next three years (following the year on which EXPAN or CONTRAC is based). An increase (decrease) in the value indicates that the industry becomes less (more) concentrated/competitive.

Time-series mean of the annual percentage change in industry research and development $(R \& D)$ expenditures over the next three years.

Time-series mean of annual abnormal return three to five years following the observation year. Monthly abnormal returns (raw returns minus benchmark returns) compounding to the annual level from. Benchmark returns are returns from CRSP value-weighted index.

Time-series mean of annual abnormal return three to five years following the observation year. Monthly abnormal returns (raw returns minus benchmark returns) compounding to the annual level from. Benchmark returns are returns from CRSP equally-weighted index.

Time-series mean of annual abnormal return three to five years following the observation year. Monthly abnormal returns (raw returns minus benchmark returns) compounding to the annual level from. Benchmark returns are returns from S\&P 500 index.

The natural logarithm of total assets.

The ratio of market value to the book value of total assets.

The age of the firm, calculated as the natural logarithm of one plus the difference between the first year when the firm appears in CRSP and the year in question. In the event that the information is unavailable in CRSP, the first year in which the firm appears in Compustat with non-missing price information is used instead.

The ratio of long-term debt to the sum of long-term debt and market value of common stock.

The ratio of the balance of property, plant, and equipment (PPE) to total assets.

The ratio of cash to PPE.

Altman's Z-Score, which is measured as the sum of 3.3 times earnings before interest and taxes, sales, 0.25 times retained earnings, and half of working capital, divided by total assets.

The ratio of cash to total assets.

An indicator variable that equals one if the company pays cash dividends during the year and zero otherwise.

An indicator variable that equals one if the company reports negative earnings before extraordinary item for the year.

The standard deviation of sales over the previous 5 years, with sales deflated by average total assets.

The standard deviation of operating cash flows over the previous 5 years, with operating cash flows deflated by average total assets. 


\section{Notes}

Note 1. Ted Greenwald, "Wall Street Loves Broadcom's CEO. Not Everyone Else Is There Yet," The Wall Street Journal, January 26, 2018, https://www.wsj.com/articles/is-broadcoms-ceo-a-champion-deal-maker-innovative-enough-1516881601.

Note 2. According to Merriam-Webster dictionary, expansionary means "tending toward expansion" and contractionary means "reducing business activities or growth".

Note 3. We choose not to use the term over/under-investment to avoid confusion as we cannot determine whether a manager picks up (forgoes) a negative (positive) NPV project due to the lack of project-level information. The fact that the investment level significantly exceeds/falls short of what is expected based on recent sales growth alone does not provide conclusive evidence as to whether managers are investing in projects with a negative NPV, even though the possibility of investing in negative NPV projects may become greater as investments reach an abnormally high level.

Note 4. In an unreported analysis, we include firm fixed effects in the baseline regressions to control for unobservable firm characteristics that may otherwise drive the above findings (Coles \& $\mathrm{Li}, 2018$; Coles \& $\mathrm{Li}, 2019$ ). The results (available upon request) do not materially change.

Note 5. Note that the strategic investment hypothesis does not exclude the possibility that more able managers strategically make expansionary investments and increase the firm's future performance out of career or reputation concerns. In that case, firms' and managers' interests are aligned.

Note 6. See Stein (2003) for a survey of the related literature.

Note 7. Google sold units of the Motorola for around 6 billion dollars. So Google's net loss in this transaction $\begin{array}{lllll}\text { amounts } & \text { to } & 3.6 & \text { billion } & \text { dollars. }\end{array}$ https://gigaom.com/2014/01/30/google-paid-4b-for-patents-why-the-motorola-deal-worked-out-just-fine/.

Note 8. https://googleblog.blogspot.com/2014/01/lenovo-to-acquire-motorola-mobility.html.

Note 9. See, for example, Leonid Bershidsky, "Google's Brilliant, Money Losing Motorola Deal," Bloomberg, January 30, 2014, https://www.bloomberg.com/view/articles/2014-01-30/google-s-intellectual-gain-from-motorola, and Gordon Kelly, How Google Used Motorola to Smack down Samsung - Twice," Forbes, February 10, 2014, https://www.forbes.com/sites/gordonkelly/2014/02/10/how-google-used-motorola-to-smack-down-samsung-twice/\#4 e152cc921fa.

Note 10. Inputs considered in their analysis include cost of inventory, R\&D expenditures, operating leases, general and administrative expenses, and intangible assets.

Note 11. Another variable that represents changes in product market is future industry M\&A activities. We do not report analyses with this variable under the perception that, if industry M\&A activities affect the competitive landscapes of the industry, the effects would be incorporated into our measure of FUTURE CHANGE IN HHI.

Note 12. Managerial ability data are obtained from Dr. Peter Demerjian's web page (http://faculty.washington.edu/pdemerj/data.html). We thank Dr. Demerjian for sharing the data.

Note 13. We thank Professor Sam Lee at Iowa State University for providing the data. 